\title{
ANALISIS TINDAK TUTUR ASERTIF GURU DI SD INPRES DUYU
}

\author{
Adria $^{1 *}$, Syamsuddin ${ }^{1}$, Sitti Harisah ${ }^{1}$ \\ ${ }^{1}$ Program Studi Pendidikan Bahasa Indonesia Pascasarjana Universitas Tadulako \\ *Email: Adria@gmail.com
}

\begin{abstract}
This research is a qualitative research that describes the form and function of speech acts of the teachers of SD Inpres Duyu. The formulation of this research is to describe the form of the teacher's assertive speech act and to determine the function of the teacher's assertive speech act. This research method uses the flow model adopted from Huberman. This data collection is through observation, study documentation, and field notes. Based on the results of the study, it was found that the form of assertive speech acts of SD Inpres Duyu teachers consisted of speech acts stating information, expressing opinions, and concluding a conversation or a decision, while the function of speech acts for SD Inpres Duyu teachers consisted of a) The function of stating. The function of stating this intends to provide information to students in the form of orders, $b$ ) The function of expressing. The function of expressing this is in the form of conveying information on illocutionary speech acts. c) Summing function. This conclusion function consists of regulation, representational, personal and imaginative, and d) asserting function. This function gives confirmation to students by using illocutionary speech acts. Assertive speech acts contain an instrumental function in expressing information, changing attitudes and beliefs, changing behavior and encouraging students to take action as a form of response to the teacher.
\end{abstract}

Keywords: Assertive Speech Act; Teacher; Duyu Inpres Elementary School

\begin{abstract}
ABSTRAK
Penelitian ini adalah penelitian kualitatif yang mendiskripsikan bentuk dan fungsi tindak tutur guru SD Inpres Duyu. Adapun rumusan penelitian ini adalah untuk mendiskripsikan bentuk tindak tutur asertif guru dan untuk mengetahui fungsi tindak tutur asertif guru. Metode penelitian ini menggunakan model alir yng diadopsi dari Huberman. Pengumpulan data ini melalui observasi, studi dokumentasi, dan catatan lapangan. Berdasarkan hasil penelitin ditemukan bahwa bentuk tindak tutur asertif guru SD Inpres Duyu terdiri atas tindak tutur menyatakan informasi, mengemukakan pendapat, dan menyimpulkan pembicaraan atau suatu keputusan sedangkan fungsi tindak tutur guru SD Inpres Duyu terdiri dari a) Fungsi menyatakan. Fungsi menyatakan ini bermaksud memberikan informasi kepada peserta didik dalam bentuk perintah, b) Fungsi mengemukakan. Fungsi mengemukakan ini dalam bentuk menyampaikan informasi tindak tutur ilokusi. c) Fungsi menyimpulkan. Fungsi menyimpulkan ini terdiri dari regulasi, representasional, personal dan imajenatif, dan d) Fungsi menegaskan. Fungsi ini memberi penegasan kepada siswa dengan menggunakan tindak tutur ilokusi. Tindak tutur asertif mengandung fungsi instrumental dalam menyatakan informasi, mengubah sikap dan keyakinan, mengubah perilaku dan mendorong menggerakkan peserta didik untuk melakukan suatu tindakan sebagai bentuk respon kepada guru.
\end{abstract}

Kata Kunci: Tindak Tutur Asertif; Guru; SD Inpres Duyu

Submisi: 18 Agustus 2021 


\section{Pendahuluan}

Guru dan peserta didik memerlukan keterampilan berbahasa sesuai dengan konteks pembicaraan. Mereka tidak hanya sekadar menggunakan bahasa, tetapi juga harus melihat situasi kelas yang diciptakan guru dan peserta didik (formal, tidak terlalu formal, atau informal), situasi khusus (faktor psikologis: kognitif, senang, bosan, jengkel, dan sebagainya), aturan-aturan yang berlaku di kelas. Di samping itu, untuk menjalin komunikasi yang baik perlu diperhatikan norma sosial budaya yang melatarbelakangi kehidupan sosial peserta didik. Hal ini sejalan sengan ungkapan Daimun (2008:2) bahwa pada prinsipnya penggunaan bahasa dalam percakapan yang terjadi antara guru dan peserta didik di kelas tidak dapat dipisahkan dari pengaruh faktor interaksi sosial. Oleh karena itu, penggunaan bahasa dalam percakapan di kelas dapat dipahami sebagai penggunaan bahasa dalam percakapan dalam interaksi sosial. Tindak tutur ini dapat disampaikan dengan berbagai macam cara berdasarkan.

Tindak tutur yang relevan dengan kondisi pandemi covid-19 adalah tindak tutur asertif yang dilakukan melalui tulisan di media sosial WhatsApp (WA).Aktivitas tutur dijelaskan oleh (Purba, 2011) yaitu bahwa dalam proses komunikasi terdapat tiga komponen terkait yaitu: partisipan, hal yang diinformasikan, dan alat (bahasa) dengan dua gejala yang dominan yaitu tindak tutur dan peristiwa tutur.Setiap peristiwa tutur terbatas pada kegiatan atau aspek-aspek kegiatan yang secara langsung diatur oleh kaidah atau norma bagi penutur,seperti bahasa lisan tertulis, isyarat, dan lain-lain; norm of interaction mengacu pada aturan dalam berinteraksi; dan genre mengacu pada bentuk penyampaian suatu pesan, baik dalam bentuk puisi, prosa, do'a dan lain-lain (Mu, 2019).

Tindak tutur yang relevan dengan kondisi pandemi covid-19 adalah tindak tutur asertif yang dilakukan melalui tulisan di media sosial WhatsApp (WA).Aktivitas tutur dijelaskan oleh (Purba, 2011) yaitu bahwa dalam proses komunikasi terdapat tiga komponen terkait yaitu: partisipan, hal yang diinformasikan, dan alat (bahasa) dengan dua gejala yang dominan yaitu tindak tutur dan peristiwa tutur.Setiap peristiwa tutur terbatas pada kegiatan atau aspek-aspek kegiatan yang secara langsung diatur oleh kaidah atau norma bagi penutur,seperti bahasa lisan tertulis, isyarat, dan lain-lain; norm of interaction mengacu pada aturan dalam berinteraksi; dan genre mengacu pada bentuk penyampaian suatu pesan, baik dalam bentuk puisi, prosa, do'a dan lain-lain $(\mathrm{Mu}, 2019)$.

Richard dan Allan dalam (Prayitno, 2009) mendefinisikan tindak tutur sebagai tindak tutur yang menjadi unit fungsional dalam komunikasi. Tindak tutur adalah perilaku berbahasa seseorang dalam sebuah peristiwa tutur. Dibutuhkan konteks dalam sebuah peristiwa tutur (Nurinna Arifiany, Maharani P. Ratna, 2016).Guru dan peserta didik memerlukan keterampilan berbahasa sesuai dengan konteks pembicaraan. Hal ini sejalan dengan ungkapan Daimun (2008:2) bahwa pada prinsipnya penggunaan bahasa dalam percakapan yang terjadi antara guru dan peserta didik di kelas tidak dapat dipisahkan dari pengaruh faktor interaksi sosial, sehingga penggunaan bahasa dalam percakapan di kelas dapat dipahami sebagai penggunaan bahasa dalam percakapan dalam interaksi sosial. Tindak tutur ini dapat disampaikan dengan berbagai macam cara.

Dell Hymes dalam (Yayat Sudaryat, 2006) menjelaskan bahwa komponen tindak tutur (komponen of speech) yang mempengaruhi perilaku berbahasa dapat disingkat menjadi "speaking" yang fonem awalnya mengacu pada: $\mathrm{S}$ (etting and scene); $\mathrm{P}$ (artisipants); $\mathrm{E}$ (nd purpose an goal); A (ct squences); K (ey tone or spirit of act) I (nstrumenttalities); N (orms of interaction and interpretation); dan $\mathrm{G}$ (enres).

Urutan tindak tutur berbeda-beda, misalnyasebuah pidatoadalah percakapannya mempunyai kultur sapaan, salam, introduksi, isi, dan penutup. Sementara, urutan tindak tutur yang lebih umum, ialah: pendahuluan, isi dan penutup 
Austin, dalam (Yayat Sudaryat, 2006).Piranti tindak tutur dikembangkan Leech menjadi: tindak tutur: asertif; komisif, ekspresif, deklaratif, dan rogatif.

Chaer (dalamWahyuni dkk., 2018) menjelaskan jika peristiwa tutur merupakan gejala sosial dan terdapat interaksi antara penutur dalam situasi dan tempat tertentu, maka tindak tutur lebih cenderung sebagai gejala individual, bersifat psikologis dan ditentukan oleh kemampu-an bahasa penutur dalam menghadapi situasi tertentu.

\section{Tindak Tutur Asertif}

Bentuk tindak tutur menurut Yayat Sudaryat dalam (2006) bentuk tindak tutur asertif dapat dimasukkan ke dalam tindak tutur impositif sedangkan bentuk tindak tutur rogatif dapat dimasukkan ke dalam bentuk tindak tutur asertif. Bentuk tindak tutur asertif adalah tindak tutur yang digunakan untuk mendorong atau menyuruh seseorang.

Asertif adalah tindakan ilokusi yang berpegang pada kebenaran proposisi (Rahayu, 2011). Tindak tutur asertif melibatkan pembicara pada kebenaran proposisi yang diekspresikan, misalnya: menyatakan, memberitahukan, menyarankan, membanggakan, mengeluh, menuntut, dan melaporkan yang cenderung bersifat netral dari segi kesopansantunan sehingga dapat dimasukkan ke dalam kategori kolaboratif(Saufi, 2018).Searle (Tidar et al., 2020) mengemukakan tindak tutur asertif sebagai tindak tutur yang melibatkan penutur pada kebenaran hal yang diungkapkannya.Bentuk tindak tutur asertif: menyatakan, memberitahukan, menyarankan, membanggakan, mengeluh, menuntut, dan melaporkan (Tidar et al., 2020).

Yuliana et.al (2013) meneliti tindak tutur asertif pada kegiatan belajar mengajar yang dianalisis dengan metode interaktif. Sari (2016) membahas tentang fungsi asertif dari tindak tutur yang dihubungakan dengan indikator pencapaian kompetensi yang tercantm pada silabus kelas delapan mata pelajaran Bahasa Indonesia (Dede \&
Suryadi, 2019).Tindak tutur asertif adalah bentuk tutur yang mengikat penutur pada kebenaran proposisi yang diungkapkan,contoh: (1) Presiden Republik Indonesia adalah bapak Joko Widodo (menyatakan) dan (2) kakak saya yang pertama bernama Arief dan kakak saya yang kedua bernama Bayu (menyatakan) (Wahyuni et al., 2018).

Tindak tutur asertif yang digunakan oleh guru dalam proses pembelajaran bahasa Indonesia di kelas banyak mengandung tindak tutur yang merupakan informasi secara berulang-ulang dengan menggunakan penekanan yang sama pada setiap pengulangannya. Bentuk komunikasi asertif dinyatakan oleh komunikator jika pernyataan komunikan dan komunikator mempunyai pendapat yang sama. Tindak tutur asertif adalah suatu tindak tutur yang terikat pada kebenaran preposisi yang diungkapkan, artinya bahwa tindak tutur tersebut dinyatakan sesuai dengan keadaan sebenarnya.

Bentuk komunikasi asertif adalah bentuk komunikasi yang menjelaskan apa dan bagaimana sesuatu itu sesuai dengan keadaan sebenarnya. Bentuk dan fungsi tindak tutur antara guru dan peserta didik adalah bagian integral dari percakapan di kelas. Tindak tutur dapat bervariasi sesuai dengan konteks dan tujuan tindak tutur. Konteks-konteks ini yang menjadi pemicu munculnya tindak tutur-tindak tutur dalam pembelajaran.

Kesesuaian konteks dan juga kevariatifan kemunculan membuat tindak tutur dalam percakapan menjadi sangat menarik untuk diteliti.Komunikasi yang terjadi antara guru dan Tarmini (n.d.) dalam penelitiannya menjelaskan bahwa representasi kekuasaan pada tindak tutur asertif guru meliputi (1) representasi kekuasaan pada tindak tutur asertif guru dalam menegaskan, guru menggunakan kekuasaan keahlian dan kekuasaan jabatan, (2) representasi kekuasaan pada tindak tutur asertif guru dalam menunjukkan, guru menggunakan kekuasaan keahlian, (3) representasi kekuasaan pada tindak tutur 
asertif guru dalam mempertahankan, guru menggunakan kekuasaan paksaan, (4) representasi kekuasaan pada tindak tutur asertif guru dalam menilai, guru menggunakan kekuasaan keahlian dan kekuasaan penghargaan.

Umumnya di masa normal tindak tutur disampaikan secara lisan,namun pembatasan sosial di masa pandemic covic19 komunikasi dilakukan secara tindak langsung melalui media sosial. Informasiinformasi disampaikan sesuai dengan konteks tujuan dilakukan tindak tutur sehingga bentuk tindak tutur yang gunakan untuk setiap tindak tutur berbeda-beda berdasarkan kebutuhan antara guru dan siswa dalam kaitannya dengan informasi pembelajaran.

Tujuan penelitian adalah mendeskripsikan bentuk dan fungsi tindak tutur asertif guru di SD Inpres Duyu. Hasil penelitian diharapkan dapat bermanfaat dalam pengembangan ilmu penge-tahuan yang berkaitan dengan bentuk dan fungsi tindak tutur asertif guru dalam kegiatan pembelajaran yang dilakukan melalui daring dan memberikan landasan bagi para peneliti lain dalam melakukan penelitian lain yang sejenis dalam rangka tindak tutur tentang berbagai hal yang berhubungan dengan pesan-pesan pem-belajaran dalam situasi pembatasan sosial pada kondisi atau keadaan-keadaan tertentu dan secara praktis hasil penelitian diharapkan bermanfaat penulis, guru, dan peserta didik.

\section{Metode Penelitian}

Penelitian ini adalah penelitian kualitatif deskriptif yang bersifat naturalistik untuk meng-ungkap hal yang ada di lapangan dan selanjutnya menganalisis secara induktif yang mengarahkan pada usaha menemukan teoribahasa pada tindak tutur Sudaryanto (Karsana, 2015).

Penelitian ini dilakukan di SD Inpres

Duyu Kecamatan Tatanga, Kota Palu, Provinsi Sulawesi Tengah, pada bulan November 2020 sampai Januari 2021. Informan penelitian adalah guru SD Inpres
Duyu dengan teknik pengumpul-an data pada penelitian ini terdiri atas observasi, wawancara terbuka, studi dokumen, dan catatan lapangan. Analisis data mengacu model Miles dan Huberman melalui tahapan: (1) reduksi data; (2) penyajian data; dan (3) kesimpulan atau verivikasi untuk mengetahui bentuk dan fungsi tindak tutur asertif guru di SD Inpres Duyu

\section{Hasil Penelitian dan Pembahasan}

Tindak tutur pada data (1) merupakan tindak tutur dilakukan dalam sebuah dialog untuk menyampaikan pesan yang mengandung tindak tutur asertif guru kelas I "menyatakan" sebuah informasi tentang tugas yang sudah diberikan guru dan membutuhkan respon atau jawaban dari peserta didik dengan jawaban atau respon peserta didik yang ditindaklanjuti dengan tindakan mengirimkan hasil kerja tugas yang sudah diberikan.

Tindak tutur dalam dialog tersebut yang dinyatakan sebagai informasi penting agar tugas ditulis di kertas dan dikirim kembali melalui WA hasilnya". Kesantunan berbahasa ditunjukkan dengan adanya respon peserta didik yang diwakili oleh orang tua dengan jawaban peserta didik 1"baik bu", peserta didik 2 "trimakasih informasi-nya bu", dan peserta didik 3 "iya bu".

Tindak Tutur Asertif Mengemukakan. Tindak tutur pada data (1) merupakan tindak tutur dilakukan dalam sebuah dialog untuk menyampaikan pesan yang mengandung tindak tutur asertif guru kelas I "mengemukakan pendapat" sebuah informasi kepada peserta didik agar baiknya orang tua melakukan pendampingan yang intensif dalam kegiatan anak di rumah. Tindak tutur tersebut membutuhkan respon atau jawaban dari peserta didik yang ditindaklanjuti dengan tindakan memberikan informasi untuk memberikan klarifikasi. Tindak tutur tersebut dilakukan sebagai sebuah pernyataan informasi penting agar baiknya orang tua melakukan pendampingan yang intensif dalam kegiatan anak di rumah. Mengemukakan pendapat 
dalam tindak tutur tersebut dapat diketahui dari pendapat "baiknya".

Kesantunan berbahasa ditunjukkan dengan adanya respon atau jawaban peserta didik 1 "iya bu, kami selalu mendampingi anak", peserta didik 2 "maaf bu, karena harus kerja terpaksa didampingi oleh kakannya", dan 3 "benar bu, anak kelas I masih perlu pendampingan orang tua". Informasi dari peserta didik adalah bentuk respon dengan kesantunan berbahasa melalui jawaban pesan dari guru untuk meyakinkan bahwa pesan atau informasi yang disampaikan guru dipahami dan diterima oleh peserta didik sebagai mitra tutur.

Tindak Tutur Asertif Menyimpulkan. Berdasarkan hasil penelitian ditemukan bentuk tindak tutur guru SD Inpres Duyu menyimpulkan. Tindak tutur asertif guru secara tertulis dalam WhatsApp sebagai tindak tutur pada data (1) merupakan tindak tutur dilakukan dalam sebuah dialog untuk menyampaikan pesan yang mengandung tindak tutur asertif guru kelas I dalam "menyimpulkan pesan" tentang sebuah kesimpulan kepada peserta didik bahwa peserta didik boleh mengirimkan tugas melalui group WA. Tindak tutur tersebut membutuhkan respon atau jawaban dari mitra tutur (peserta didik) yang ditindaklanjuti dengan tindakan memberikan informasi sebagai bentuk klarifikasi. Tindak tutur tersebut dilakukan sebagai sebuah kesimpulan guru yang dianggap penting bagi peserta didik agar menulis halaman sub tema dan pembelajaran, berapa semuanya ditulis agar guru tidak bingung memeriksa yang disertai dengan penguatan kepada salah satu peserta didik yang dinyatakan dengan kesimpulan bahwa peserta didik boleh mengirimkan tugas melalui group WA. Mengemukakan pendapat dalam tindak tutur tersebut dapat diketahui dari pendapat "kalau begitu" dan "boleh".

Kesantunan berbahasa ditunjukkan dengan adanya respon peserta didik yang dapat dilihat dari respon atau jawaban peserta didik dengan ucapan iya bu, trima kasih, karena covic ini jadi takut untuk antar tugas ke sekolah karena kalau antar tugas anak juga maunya ikut.

Tindak Tutur Asertif Menegaskan. Berdasarkan hasil penelitian ditemukan bentuk tindak tutur guru SD Inpres Duyu menegaskan pada WhatsApp sebagai tindak tutur pada data (1) merupakan tindak tutur dilakukan dalam sebuah dialog untuk menyampaikan pesan yang mengandung tindak tutur asertif guru kelas I dalam "menegaskan" agar tetap ada pembiasaan menulis untuk anak-anak sesuai buku kerja yang sudah dibagikan, karena untuk kelas I masih fokus baca tulisnya dipermantap. Tindak tutur tersebut membutuhkan respon atau jawaban dari peserta didikyang ditindaklanjuti dengan tindakan memberikan informasi sebagai bentuk klarifikasi sebagai sebuah penegasan yang dianggap penting agar tetap ada pembiasaan menulis untuk anak-anak sesuai buku kerja yang sudah dibagikan, karena untuk kelas I masih fokus baca tulisnya dipermantap.

Kesantunan berbahasa ditunjukkan dengan adanya respon peserta didik yang dapat dilihat dari respon atau jawaban peserta didik yang diwakili orang tua 1 "baik bu", orang tua 2 "karena sudah lancar menulis dan membaca, juga dikasih latihan mengerjakan matematika di buku-buku lain bu", dan orang tua 3 "bu bisa juga anak-anak dikasih tugas yang berbeda-beda sesuai perkembangannya, karena ada anak dari TK ada juga yang tidak".

Tindak tutur pada data merupakan tindak tutur dilakukan dalam sebuah dialog untuk menyampaikan pesan yang mengandung tindak tutur asertif guru kelas II dalam "menegaskan" agar tugas gambar benda yang diukur dengan penggaris pada halaman 9 dan benda yang diukur dengan meteran pada halaman 28 , jika tidak bias digambar, cukup menulis nomor soalnya, misalnya: gambar 1 bisa diukur dengan penggaris atau gambar 2 tidak bisa. Tindak tutur tersebut membutuhkan respon atau jawaban dari mitra tutur (peserta didik) yang ditindaklanjuti dengan tindakan 
memberikan informasi sebagai bentuk klarifikasi. Tindak tutur tersebut dilakukan sebagai sebuah penegasan yang dianggap penting agar tugas gambar benda yang diukur dengan penggaris pada halaman 9 dan benda yang diukur dengan meteran pada halaman 28, jika tidak bias digambar, cukup menulis nomor soalnya, misalnya: gambar 1 bisa diukur dengan penggaris atau gambar 2 tidak bisa.

Menegaskan dalam tindak tutur tersebut dapat diketahui dari ungkapan guru "untuk", “jika", "cukup", dan "diukur dengan". Kesantunan berbahasa ditunjukkan dengan adanya respon peserta didik yang dapat dilihat dari respon atau jawaban peserta didik yang diwakili orang tua 1 "iya bu" dan orang tua 3 "kapan dikumpul bu?".

Tindak Tutur Asertif Mengemukakan. Tindak tutur pada data (2) merupakan tindak tutur dilakukan dalam sebuah dialog untuk menyampaikan pesan yang mengandung tindak tutur asertif guru kelas II dalam "mengemukakan pendapat" sebuah informasi kepada peserta didik agar lagu yang ada di halaman $40 \mathrm{itu}$, cari di youtube, kalau tidak bisa, boleh diganti dengan lagu daerah Kaili yang kalian hafal. Tindak tutur tersebut dilakukan sebagai sebuah penyampaian pendapat guru penting bagi peserta didik agar lagu yang ada di halaman 40 itu, cari di youtube atau diganti dengan lagu daerah Kaili yang dihafal oleh peserta didik.

Mengemukakan pendapat dalam tindak tutur tersebut dapat diketahui dari pendapat "cari". Artinya, guru menginformasikan tentang pendapat guru yang diyakini penting untuk disampaikan sebagai sebuah pendapat bagi peserta didik sehingga peserta didik memahami informasi bahwa dicari di youtube atau diganti dengan lagu daerah Kaili yang dihafal oleh peserta didik. Kesantunan perbahasa ditunjukkan dengan adanya respon peserta didik yang dapat dilihat dari respon atau jawaban peserta didik dengan ucapan terima kasih terhadap pendapat yang disampaikan dalam tindak tutur guru.
Tindak tutur pada data (2) merupakan tindak tutur dilakukan dalam sebuah dialog untuk menyampaikan pesan yang mengandung tindak tutur asertif guru kelas II dalam "menyimpulkan pesan" tentang sebuah kesimpulan kepada peserta didik bahwa dengan apa yang sudah dilakukan oleh peserta didik menjadikan peserta didik peserta didik agar selalu percaya. Tindak tutur tersebut membutuhkan respon atau jawaban dari peserta didik yang ditindaklanjuti dengan tindakan memberikan informasi sebagai bentuk klarifikasi. Tindak tutur tersebut dilakukan sebagai sebuah kesimpulan guru yang dianggap penting bagi peserta didik agar peserta didik selalu percaya diri dengan yang dikerjakannya. Menyimpulkan dalam tindak tutur tersebut dapat diketahui dari kesimpulan "mantap" dan "alhamdulilah".

Kesantunan berbahasa ditunjukkan dengan adanya respon peserta didik yang dapat dilihat dari respon atau jawaban peserta didik dengan ucapan "amin bu guru, trima kasih".

Tindak tutur pada data (2) merupakan tindak tutur dilakukan dalam sebuah dialog untuk menyampaikan pesan yang mengandung tindak tutur asertif guru kelas II dalam menegaskan agar tugas gambar benda yang diukur dengan penggaris pada halaman 9 dan benda yang diukur dengan meteran pada halaman 28 , jika tidak bias digambar, cukup menulis nomor soalnya, misalnya: gambar 1 bisa diukur dengan penggaris atau gambar 2 tidak bisa. Tindak tutur tersebut membutuhkan respon atau jawaban dari peserta didik yang ditindaklanjuti dengan tindakan memberikan informasi sebagai bentuk klarifikasi. Tindak tutur tersebut dilakukan sebagai sebuah penegasan yang dianggap penting agar tugas gambar benda yang diukur dengan penggaris pada halaman 9 dan benda yang diukur dengan meteran pada halaman 28, jika tidak bias digambar, cukup menulis nomor soalnya, misalnya: gambar 1 bisa diukur dengan penggaris atau gambar 2 tidak bisa. 
Menegaskan dalam tindak tutur tersebut dapat diketahui dari ungkapan guru "untuk", “jika", "cukup", dan "diukur dengan". Kesantunan berbahasa ditunjukkan dengan adanya respon peserta didik yang dapat dilihat dari respon atau jawaban peserta didik yang diwakili orang tua 1 "iya bu" dan orang tua 3 "kapan dikumpul bu?".

Tindak tutur pada data (9) merupakan tindak tutur dilakukan dalam sebuah dialog untuk menyampaikan pesan yang mengandung tindak tutur asertif guru kelas III dalam "menyimpulkan pesan" tentang sebuah kesimpulan kepada peserta didik bahwa kalau memang tugas belum selesai, boleh dikumpulkan atau dikirimkan akhir pekan. Tindak tutur tersebut membutuhkan respon atau jawaban dari mitra tutur (peserta didik) yang ditindaklanjuti dengan tindakan memberikan informasi sebagai bentuk klarifikasi. Tindak tutur tersebut dilakukan sebagai sebuah kesimpulan guru yang dianggap penting bagi peserta didik yang belum selesai mengerjakan tugasnya boleh dikumpulkan atau dikirimkan akhir pekan. Menyimpulkan dalam tindak tutur tersebut dapat diketahui dari kesimpulan "kalau memang" dan "boleh", Artinya, guru menginformasikan kesimpulan guru yang diyakini penting untuk disampaikan sebagai sebuah kesimpulan agarpeserta didik yang belum selesai mengerjakan tugasnya boleh mengumpulkan atau mengirimkan pada akhir pekan.Kesantunan berbahasa ditunjukkan dengan adanya respon peserta didik yang dapat dilihat dari respon atau jawaban peserta didik dengan ucapan peserta didik 1 "iya bu sebaiknya diberi waktu lagi" dan peserta didik 2 "belum selesai, karena megerjakan tugas agama dan PJOK juga bu".

Klarifikasi dari peserta didik adalah bentuk respon dengan kesantunan berbahasa melalui jawaban pesan dari guru untuk meyakinkan bahwa pesan atau pendapat yang disampaikan guru dipahami dan diterima oleh peserta didik sebagai mitra tutur. Baik tindak tutur maupun respon mitra tutur disampaikan dalam bentuk kesimpulan dengan kesantunan berbahasa melalui pembatasan informasi tentang konteks pesan kesimpulan.

Tindak Tutur Asertif Mengemukakan. Tindak tutur pada data (10) merupakan tindak tutur dilakukan dalam sebuah dialog untuk menyampaikan pesan yang mengandung tindak tutur asertif guru kelas III dalam "menyimpulkan pesan" tentang sebuah kesimpulan kepada peserta didik bahwa kalau memang tugas belum selesai, boleh dikumpulkan atau dikirimkan akhir pekan. Tindak tutur tersebut membutuhkan respon atau jawaban dari mitra tutur (peserta didik) yang ditindaklanjuti dengan tindakan memberikan informasi sebagai bentuk klarifikasi. Tindak tutur tersebut dilakukan sebagai sebuah kesimpulan guru yang dianggap penting bagi peserta didik yang belum selesai mengerjakan tugasnya boleh dikumpulkan atau dikirimkan akhir pekan. Menyimpulkan dalam tindak tutur tersebut dapat diketahui dari kesimpulan "kalau memang" dan "boleh". Kesantunan berbahasa ditunjukkan dengan adanya respon peserta didik yang dapat dilihat dari respon atau jawaban peserta didik dengan ucapan peserta didik 1 "iya bu sebaiknya diberi waktu lagi" dan peserta didik 2 "belum selesai, karena megerjakan tugas agama dan PJOK juga bu".

Tindak Tutur Asertif Menyimpulkan. Tindak tutur pada data (11) merupakan tindak tutur dilakukan dalam sebuah dialog untuk menyampaikan pesan yang mengandung tindak tutur asertif guru kelas III dalam "menyimpulkan pesan" bahwa jika tugas belum selesai, boleh dikumpulkan atau dikirimkan akhir pekan. Tindak tutur tersebut membutuhkan respon atau jawaban dari mitra tutur (peserta didik) yang ditindaklanjuti dengan tindakan memberikan informasi sebagai kesimpulan yang dianggap penting bagi yang belum selesai mengerjakan tugasnya boleh dikumpulkan atau dikirimkan akhir pekan. Menyimpulkan dalam tindak tutur tersebut dapat diketahui dari kesimpulan "kalau memang" dan "boleh". 
Kesantunan berbahasa ditunjukkan dengan adanya respon peserta didik yang dapat dilihat dari respon atau jawaban peserta didik dengan ucapan peserta didik 1 "iya bu sebaiknya diberi waktu lagi" dan peserta didik 2 "belum selesai, karena megerjakan tugas agama dan PJOK juga bu".

Tindak Tutur Asertif Menegaskan.

Tindak tutur pada data (12) merupakan tindak tutur dilakukan dalam sebuah dialog untuk menyampaikan pesan yang mengandung tindak tutur asertif guru kelas III dalam "menegaskan" agar peserta didikmembaca dengan baik-baik agar mudah menyelesaikan. Menegaskan dalam tindak tutur tersebut dapat diketahui dari ungkapan guru "untuk", dan "supaya". Kesantunan berbahasa ditunjukkan dengan adanya respon peserta didik yang dapat dilihat dari respon atau jawaban peserta didik yang menyatakan "bu, saya sudah paham".

Tindak Tutur Asertif Menyatakan. Tindak tutur pada data (13) merupakan tindak tutur dilakukan dalam sebuah dialog untuk menyampaikan pesan yang mengandung tindak tutur asertif guru kelas IV dalam menyatakan pesan tentang kepada peserta didik bahwa dalam mengerjakan tugas matematika dituliskan atau dijelaskan cara menyelesaikan. Tindak tutur tersebut dilakukan sebagai sebuah pernyataan yang dianggap penting bagi peserta didik. Kesantunan berbahasa ditunjukkan dengan adanya respon peserta didik yang dapat dilihat dari respon atau jawaban peserta didik dengan ucapan peserta didik 1 "saya langsung jawab pilihannya bu", peserta didik 2 "bu, saya dengan gambarnya juga", dan peserta didik 3 "iya bu, saya sudah menggunakan cara kerjanya".

Tindak Tutur Asertif Mengemukakan. Tindak tutur pada data (14) merupakan tindak tutur dilakukan dalam sebuah dialog untuk menyampaikan pesan yang mengandung tindak tutur asertif guru kelas IV dalam "mengemukakan" tentang sebuah informasi kepada peserta didik bahwa dalam mengerjakan tugas matematika dituliskan atau dijelaskan cara menyelesaikan. Tindak tutur tersebut membutuh-kan respon atau jawaban dari mitra tutur (peserta didik) yang ditindaklanjuti dengan tindakan memberikan informasi sebagai bentuk klarifikasi. Mengemukakan dalam tindak tutur tersebut dapat diketahui dari kesimpulan "dijelaskan", artinya guru menginformasikan kesimpulan guru yang diyakini penting untuk disampaikan sebagai sebuah kesimpulan agar peserta didik dalam mengerjakan tugas matematika metuliskan atau menjelaskan cara penyelesaiannya.

Kesantunan berbahasa ditunjukkan dengan adanya respon peserta didik yang dapat dilihat dari respon atau jawaban peserta didik dengan ucapan peserta didik 1 "saya langsung jawab pilihannya bu", peserta didik 2 "bu, saya dengan gambarnya juga", dan peserta didik 3 "iya bu, saya sudah menggunakan cara kerjanya”.

Tindak Tutur Asertif Menyimpulkan. Tindak tutur pada data (15) merupakan tindak tutur dilakukan dalam sebuah dialog untuk menyampaikan pesan yang mengandung tindak tutur asertif guru kelas IV dalam "menyimpulkan pesan" tentang sebuah kesimpulan kepada peserta didik bahwa dalam mengerjakan tugas matematika dituliskan atau dijelaskan cara menyelesaikan. Tindak tutur tersebut dilakukan sebagai sebuah kesimpulan guru yang dianggap penting bagi peserta didik agar dalam mengerjakan tugas matematika menuliskan dan menjelaskan cara penyelesaian. Menyimpulkan dalam tindak tutur tersebut dapat diketahui dari kesimpulan dituliskan dan dijelaskan artinya guru menginformasikan kesimpulan guru yang diyakini penting untuk disampaikan sebagai sebuah kesimpulan agar peserta didik dalam mengerjakan tugas matematika metuliskan atau menjelaskan cara penyelesaiannya.

Kesantunan berbahasa ditunjukkan dengan adanya respon peserta didik yang dapat dilihat dari respon atau jawaban peserta didik dengan ucapan peserta didik 1 "saya langsung jawab pilihannya bu", peserta didik 2 "bu, saya dengan gambarnya 
juga", dan peserta didik 3 "iya bu, saya sudah menggunakan cara kerjanya".

Tindak Tutur Asertif Menegaskan Tindak tutur pada data (16) merupakan tindak tutur dilakukan dalam sebuah dialog untuk menyampaikan pesan yang mengandung tindak tutur asertif guru kelas I dalam menegaskan agar yang sudah mengambil modul, dikerjakan sesuai urutan pembelajaran mulai dari pembelajaran tema 6 sub tema 1 jadi, setiap hari pembelajaran dan dikumpulkan setiap 1 minggu.

Tindak tutur tersebut dilakukan sebagai sebuah penegasan yang dianggap penting agar mengambil modul, mengerjakan sesuai urutan, tugas dikumpulkan setiap 1 minggu. Menegaskan dalam tindak tutur tersebut dapat diketahui dari ungkapan guru "sesuai", "mulai dari", dan "setiap".

Kesantunan berbahasa ditunjukkan dengan adanya respon peserta didik yang dapat dilihat dari respon atau jawaban peserta didik yang diwakili orang tua 1 "iya bu, nanti saya sampaikan juga dengan teman-teman yang berdekatan". Tindak Tutur Asertif Menyatakan. Tindak tutur pada data (17) merupakan tindak tutur dilakukan dalam sebuah dialog untuk menyampaikan pesan yang mengandung tindak tutur asertif guru kelas $\mathrm{V}$ menyatakan sebuah informasi kepada peserta didik segerah menyelesaika tugasnya. Menyatakan dalam tindak tutur tersebut dapat diketahui dari pernyataan bahwa tugas yang ada pada pembelajaran tema 6 sub tema 3 segerah diselesaikan dan besok membahas materi pada sub tema 4 .

Kesantunan berbahasa ditunjukkan dengan adanya respon peserta didik yang dapat dilihat dari respon atau jawaban peserta didik "saya tidak mengerti soal terakhir di pembelajaran 6 sub tema 6 . Informasi dari peserta didik membutuhkan tindaklanjut dari guru untuk menjelaskan kembali materi tersebut sehingga peserta didik dapat mengerti dan memahami apa yang harus dilakukan terhadap tugas yang diberikan.
Tindak Tutur Asertif Mengemukakan. Tindak tutur pada data (18) merupakan tindak tutur dilakukan dalam sebuah dialog untuk menyampaikan pesan yang mengandung tindak tutur asertif guru kelas $\mathrm{V}$ dalam "mengemukakan" tentang sebuah pendapat kepada peserta didik agar menjawab soal tidak harus menggunakan contoh dari buku atau yang dijelaskan guru tetapi dapat menggunakan acara yang diyakini benar dengan cara paling mudah menurut peserta didik. Mengemukakan pendapat dalam tindak tutur tersebut dapat diketahui dari pendapat "boleh" dan "selain".

Kesantunan berbahasa ditunjukkan dengan adanya respon peserta didik yang dapat dilihat dari respon atau jawaban peserta didik 1 "oh iya bu, saya punya acara mengerjakan yang saya pahami", peserta didik 2 "saya mengerjakan du acara bu, seperti yang ibu jelaskan dan ada juga cara lain saya liat di youtube", dan peserta didik 3 "saya ikut contoh saja bu, boleh kan?"

Tindak Tutur Asertif Menyimpulkan. Tindak tutur pada data (19) merupakan tindak tutur dilakukan dalam sebuah dialog untuk menyampaikan pesan yang mengandung tindak tutur asertif guru kelas $\mathrm{V}$ dalam "menyimpulkan pesan" tentang sebuah kesimpulan bahwa besok yang tidak hadir melanjutkan diskusi hari ini dan yang hadir besok menyelesaikan tugasnya masing-masing. Tindak tutur tersebut membutuh-kan respon atau jawaban dari mitra tutur (peserta didik) yang ditindaklanjuti dengan tindakan memberikan informasi sebagai bentuk klarifikasi.

Kesantunan berbahasa ditunjukkan dengan adanya respon peserta didik yang dapat dilihat dari respon atau jawaban peserta didik dengan ucapan peserta didik 1 "iya bu, kemarin pulsa tidak ada", peserta didik 2 "kemarin HP dipakai kakak untuk belajar online juga", dan peserta didik 3 "kalau ibu kirim di group WA, Hp dibawah bapak pergi kerja".

Tindak Tutur Asertif Menegaskan. Tindak tutur pada data (20) merupakan tindak tutur dilakukan dalam sebuah dialog 
untuk menyampaikan pesan yang mengandung tindak tutur asertif guru kelas $\mathrm{V}$ dalam "menegaskan" agar peserta didik menyanyi kemudian dividio dan dikirim Tindak tutur tersebut membutuhkan respon atau jawaban dari mitra tutur (peserta didik) yang ditindaklanjuti dengan tindakan memberikan informasi sebagai bentuk klarifikasi. Tindak tutur tersebut dilakukan sebagai sebuah penegasan yang dianggap penting. Klarifikasi dari peserta didik adalah bentuk respon dengan kesantunan berbahasa melalui jawaban pesan dari guru untuk meyakinkan bahwa pesan atau pendapat yang disampaikan guru dipahami dan diterima oleh peserta didik sebagai mitra tutur.

Tindak Tutur Asertif Menyatakan. Tindak tutur pada data (21) merupakan tindak tutur dilakukan dalam sebuah dialog untuk menyampaikan pesan yang mengandung tindak tutur asertif guru kelas VI dalam menyatakan informasi kepada peserta didik agar "perempuan mengisi kolom yang diisi oleh perempuan" dan "laki-laki mengisi kolom yang diisi oleh anak laki-laki". Kesantunan berbahasa ditunjukkan dengan adanya respon peserta didik yang dapat dilihat dari respon atau jawaban peserta didik dengan ucapan "iya bu, terima kasih" untuk meyakinkan bahwa pesan atau pendapat yang disampaikan guru dipahami dan diterima oleh peserta didik. Tindak Tutur Asertif Mengemukakan. Tindak tutur pada data (22) merupakan tindak tutur dilakukan dalam sebuah dialog untuk menyampaikan pesan kepada peserta didik agar menulis halaman sub tema dan pembelajaran agar guru tidak bingung memeriksa yang disertai dengan penguatan kepada salah satu peserta didik yang dinyatakan dengan pendapat seperti Nia Kurniati, bagus pekerjaannya. Mengemukakan dalam tindak tutur tersebut dapat diketahui dari pendapat "supaya" dan "seperti". Guru menginformasikan pendapat guru yang diyakini penting untuk disampaikan sebagai sebuah pendapat bagi peserta didik sehingga peserta didik memahami bahwa peserta didik boleh boleh mencari sumber lain selain buku peserta didik, seperti di internet atau surat kabar.

Tindak Tutur Asertif Menyimpulkan Tindak tutur pada data (23) merupakan tindak tutur dilakukan dalam sebuah dialog untuk menyampaikan pesan yang mengandung tindak tutur asertif guru kelas IV dalam "menyimpulkan" bahwa dalam mengerjakan tugas matematika dituliskan atau dijelaskan cara menyelesaikan. Tindak tutur tersebut dilakukan sebagai sebuah kesimpulan guru yang dianggap penting bagi peserta didik agar dalam mengerjakan tugas matematika menuliskan dan menjelaskan cara penyelesaian. Kesantunan perbahasa ditunjukkan dengan adanya respon peserta didik melalui pembatasan informasi tentang konteks pesan yang berbentuk kesimpulan. Tindak Tutur Asertif Menegaskan. Tindak tutur pada data (24) merupakan tindak tutur dilakukan dalam sebuah dialog untuk menyampaikan pesan yang mengandung tindak tutur asertif guru kelas VI dalam "menegaskan" agar buku belum di bawah ke sekolah karena masih ada pembelajaran berikutnya. Kalau menyetor tugas dituliskan sub temanya dan pembelajaran berapa. Tindak tutur tersebut membutuhkan respon atau jawaban dari mitra tutur (peserta didik) yang ditindaklanjuti dengan tindakan memberikan informasi sebagai bentuk klarifikasi. Tindak tutur tersebut dilakukan sebagai sebuah penegasan yang dianggap penting agar buku belum di bawah ke sekolah karena masih ada pembelajaran berikutnya. Kalau menyetor tugas dituliskan sub temanya dan pembelajaran berapa.

Pernyataan guru terkait dengan pembelajaran yang dilakukan secara daring seperti di kemukakan oleh guru kelas Ibahwa pembelajaran dilakukan menggunakan media WA dalam bentuk chatting. Penggunaan WA sebagai alternatif pilihan, karena WA adalah media paling mudah digunakan dan semua peserta didik dapat menggunakannya dengan sedikit pendampingan orang tua. Karena peserta didik kelas I masih membutuhkan pendampingan khususnya peserta didik 
yang belum lancar membaca dan belum mampu menulis kalimat dengan baik, sehingga komunikasi dilakukan dengan orang tua. Menurut guru kelas I, komunikasi dilakukan khususnya menyampaikan informasi-informasi penting seperti: tugastugas yang harus diselesaikan dalam buku peserta didik, pengumpulan tugas-tugas, praktik-praktik yang dilakukan secara visual dan membutuhkan penilaian langsung oleh guru, kontrol keaktifan belajar peserta didik serta hal-hal lain yang berhubungan dengan kegiatan pembelajaran yang harus dilakukan peserta didik di rumah melalui pemantauan dan pendampingan orang tua.

Pernyataan guru kelas II pada dasarnya seperti yang dilakukan oleh guru kelas I, yaitu menggunakan media WA dalam bentuk chatting dengan alasan yang sama yaitu kemudahan penggunaan dan semua peserta didik dapat menggunakan dengan baik. Umumnya peserta didik sudah dapat membaca dan menulis dengan baik, sehingga lebih pendampingan orang tua hampir tidak ada, dan peserta didik dapat berkomunikasi dengan lancar dan aktif dengan guru.

\section{Informasi-informasi direspon}

langsung oleh peserta didik dan guru yakin bahwa yang disampaikan oleh guru dipahami dengan baik oleh peserta didik, yang ditunjukkan dari tugas-tugas yang disetor kepada guru. Termasuk menyampaikan alasan-alasan yang logis. Umumnya peserta didik dapat menyampaikan kesulitannya dan meminta penjelasan lebih lanjut oleh guru baik melalui. Pernyataan guru terkait dengan pemahaman guru tentang aspek-aspek yang perlu diperhatikan dalam menyampaikan pesan pembelajaran dan jenis tindak tutur yang digunakan guru, umumnya guru bingung dan tidak pernah mendengar istilah tindak tutur secara khusus.

Berdasarkan hasil wawancara terbuka, dapat disimpulkan bahwa kesalahan-kesalahan penggunaan bahasa merupakan satu permasalahan yang selama ini terjadi di lingkungan pendidikan khususnya sekolah dasar (SD Inpres Duyu) yang tidak terpikirkan untuk dilakukan dengan baik dan benar dan hanya terfokus pada tersampaikannya pesan dari guru dan peserta didik dapat menerimanya dengan memahami pesan tersebut yang diikuti dengan tindakan-tindakan yaitu menyelesaikan tugas-tugas yang disampaikan oleh guru.

\section{Fungsi Tindak Tutur Guru di SD Inpres Duyu}

Fungsi tindak tutur dalam konteks linguistik dewasa ini mulai mendapat perhatian dari peneliti dan pakar bahasa di Indonesia. Bidang ini cenderung mengkaji fungsi ujaran atau fungsi bahasa dalam bentuk atau strukturnya, dengan kata lain pragmatik cenderung ke fungsionalisme bekerja ke formalisme. Fungsi tindak tutur asertif dalam penelitian ini sejalan dengan fungsi menurut Tarigan (2015), antara lain yaitu: (1) fungsi regulasi yaitu sebagai alat untuk mengatur tingkahlaku peserta didik, misalnya: menyatakan persetujuan, mengemukkan pendapat, men-yimpulkan suatu kesepakatan, dan memberi-kan pesan dengan modus menegaskan untuk melakukan tindakan-tindakan tertentu sebagai bentuk respon pada apa yang dituturkan guru; (2) fungsi representasional yaitu membuat pernyataan-pernyataan, menyampaikan fakta-fakta dan pengetahuan, menjelaskan dan melapor-kan, dengan perkataan lain menggambarkan realitas yang sebenarnya seperti yang dilihat seseorang. Fungsi representasional tindak tutur guru di SD Inpres Duyu, dapat diketahui dari aktivitas guru menyatakan persetujuan, me-ngemukkan pendapat, menyimpulkan suatu kesepakatan Fungsi interaksional bertujuan positif untuk membuat terjalinnya hubungan yang baik antara kepala sekolah dan siswa serta antara guru dan peserta didik; (3) fungsi personal berfungsi untuk mengekspresikan perasaan, emosi, pribadi, serta reaksireaksi yang dalam; (4) fungsi heuristik atau fungsi diperoleh dari ilmu pengetahuan dan mempelajari seluk beluk lingkungan dan seringkali disampaikan dalam bentuk pertanyaan-pertanyaan yang menuntut 
jawaban, sebagaimana dilakukan oleh peserta didik di SD Inpres Duyu; dan (5) fungsi imajinatif bertujuan menciptakan sistem-sistem atau gagasan-gagasan yang bersifat imajinatif sebagaimana dilihat dari setiap bentuk tindak tutur seperti menyatakan persetujuan, me-ngemukkan pendapat, menyimpulkan suatu kesepakatan fungsi interaksional bertujuan positif untuk membuat terjalinnya hubungan yang baik antara kepala sekolah dan siswa serta antara guru dan peserta didik.

Fungsi dari setiap tindak tutur guru adalah fungsi komunikasi yang meliputi fungsi-fungsi berdasarkan konteks tindak tutur serta seberapa pentingnya setiap tuturan dengan masing-masing modus untuk dituturkan.

\section{Fungsi Tindak Tutur Asertif Menyatakan}

Fungsi tindak tutur guru dalam bentuk tindak tutur asertif menyatakan informasi memiliki fungsi regulasi, representasional, dan imajinatif, seperti:

GK.1: untuk kelas I tugasnya ditulis $\underline{d i}$ kertas dan boleh dikirim kembali melalui WA hasilnya.

GK.2 : dari puisi taman bungaku, anak-anak dapat menjawab 5 soal $\underline{d i}$ atas. Bila anak belum lancar membaca, orang tua bisa membantunya, tapi biarkan anak yang menjawab dari hasil menyimak bacaan puisi.

GK.3 : disampaikan kepada peserta didik yang belum mengumpulkan tugasnya secepatnya dikumpulkan. Boleh diantar $\underline{d i}$ sekolah atau dikirim kembali melalui group.

GK.4: yang tidak mengisi daftar hadir $\underline{d i}$ group, akan dinyatakan alpa.

GK.5: pembelajaran tema 6 sub tema 3 segerah diselesaikan tugasnya, karena besok kita membahas materi pada sub tema 4.

GK.6: yang belum mengambil modul, besok segerah kesekolah tetapi tetap dikumpul hari senin.

Fungsi masing-masing tindak tutur guru (kelas I-VI) yaitu untuk menginformasikan atau mengatakan tentang yang harus dilakukan peserta didik, juga sebagai upaya memberikan perintah agar peserta didik dapat melakukan sesuai dengan apa yang diinformasikan. Melihat respon orang tua (mewakili peserta didik khususnya kelas rendah) dan peserta didik kelas atas, yang menerima informasi dengan baik dan memahami informasi sebagai sebuah komunikasi dengan guru sebagai lawan tutur dalam hal ini penyampai informasi.

\section{Fungsi Tindak Asertif Mengemukakan}

Fungsi tindak tutur guru dalam bentuk tindak tutur asertif dengan modus mengemukakan memiliki fungsi memiliki fungsi regulasi, representasional, dan imajinatif, seperti:

GK.1: baiknya orang tua melakukan pendampingan yang intensif dalam

GK.2 : lagu yang ada di halaman $40 \mathrm{itu}$, cari di youtube, klu tid bisa, boleh boleh diganti dengan lagu daerah Kaili yang kalian hafal.

GK.3 : jika kalian kurang paham dan tidak dapat berkoordinasi dengan guru, boleh bertanya kepada siapa saja yang ada di rumah yang lebih paham.

GK.4: kalian boleh mencari sumber lain selain buku peserta didik, seperti di internet atau surat kabar.

GK.5 : menjawab soal, tidak harus menggunakan contoh dari buku atau yang dijelaskan guru. Kalau kalian puny acara lain menyelesaikan dan kalian yakini benar dengan cara paling mudah menurut kalian silakan.

GK.6 : ditulis juga halaman sub tema dan pembelajaran berapa semuanya ditulis, supaya ibu tidak bingung memeriksa. Seperti Nia Kurniati, bagus pekerjaannya.

Fungsi bahasa tulis berbeda dengan informasi dalam bahasa lisan yang umumnya dapat dipahami dengan baik jika penutur memberikan informasi dengan pengucapan yang benar untuk dapat dipahami oleh baik oleh pemberi informasi maupun penerima informasi, oleh karena itu 
hasil tindak tutur asertif guru sebagai bentuk informasi penting untuk guru menggunakan penulisan singkatan yang benar untuk menanamkan konsep-konsep berbahasa lisan dengan baik dan benar bagi para peserta didik. Penulisan (singkatan) yang tidak sesuai dengan aturan penggunaan bahasa Indonesia yang baik dan benar, namun pada dasarnya penggunaan singkatan-singkatan tersebut dapat dipahami karena baik oleh penutur (yang menyampaikan informasi) dan lawan tutur (sebagai penerima informasi) memiliki kebiasaan yang sama yaitu menggunakan singkatan-singatan yang berlaku umum walaupun tidak sesuai dengan kaidah penggunaan bahasa Indonesia yang baik dan benar.

\section{Fungsi Tindak Tutur Asertif Menyimpulkan}

Fungsi tindak tutur guru dalam bentuk tindak tutur asertif, memiliki fungsi regulasi, representasional, personal dan imajinatif, seperti:

GK.1 : kalau begitu tugas anak-anak boleh dikirim di group saja.

GK.2: Mantap, selalu percaya diri nak. Alhamdulilah, makin rajin nak.

GK.3: kalau memang tugas kalian belum selesai, boleh dikumpulkan atau dikirimkan akhir pekan.

GK.4 : tugas dalam mengerjakan matematika dituliskan atau dijelaskan cara menyelesaikan.

GK.5 : karena hari ini tidak semua hadir dalam diskusi online kita, jadi besok yang tidak hadir kita lakukan lanjutkan diskusi hari ini dan yang hadir hari ini silakan waktunya besok digunakan menyelesaikan tugasnya masing-masing.

GK.6 : hari ini kita masuk pembelajaran 4, tugas yang dikerjakan hal. $65 y g$ dikerjakan hal 65 yang perempuan mengisi kolom yang diisi oleh anak perempuan begitu juga untuk lakilaki yang diisi oleh anak laki-laki”. Kemudian halaman 67 mengamati gerak tari kreasi bentuk tunggal, halaman 68 ayo berlatih mengisi kolom tentang pendapatmu mengenai gerakan tari.

Tindak tutur asertif guru dalam pembelajaran terkait dengan menyampaikan sebuah kesimpulan, umumnya tidak terlihat dalam komunikasi tulisan pada percakapan guru dan peserta didik di SD Inpres Duyu. Kesimpulan-kesimpulan yang teridentifikasi dalam setiap percakapan penyampaian-penyapaian sebelumnya sebagai bentuk penerimaan guru terhadap respon peserta didik dalam setiap percakapan yang dilakukan secara tertulis sebagai bentuk komunikasi kegiatan pembelajaran. Penyimpulan untuk materi pembelajaran hanya dilakukan dengan keyakinan bahwa peserta didik mampu menyelesaikan pekerjaannya sesuai dengan konteks materi yang dipelajari yang diinformasikan dalam percakapanpercakapan tertulis dalam WA.

\section{Fungsi Tindak Tutur Asertif Menegaskan}

Fungsi tindak tutur guru dalam bentuk tindak tutur asertif, memiliki fungsi regulasi, representasional, dan imajinatif, seperti:

GK.1 : tetap ada pembiasaan menulis untuk anak-anak sesuai buku kerja yang sudah dibagikan, karena untuk kelas I masih fokus baca ulisnya dipermantap.

GK.2: untuk tugas gambar benda yang diukur dengan penggaris pada halaman 9 dan benda yang diukur dengan meteran pada halaman 28 , jika tidak bias digambar, cukup menulis nomor soalnya, misalnya: gambar 1 bisa diukur dengan penggaris atau gambar 2 tidak bisa".

GK.3 : untuk pembelajaran 6 sub tema 1 pada tema 6, dibaca baik-baik soalnya supaya bisa diselesaikan dengan mudah.

GK.4: yang sudah mengambil modul, dikerjakan sesuai urutan pembelajaran ya, mulai dari pembelajaran tema 6 sub tema 1 jadi, 
setiap hari 1 pembelajaran dan dikumpulkan setiap 1 minggu.

GK.5 : kalian menyanyi, kemudian dividio dan dikirim.

GK.6 : bukunya tidak usa dulu di bawah ke sekolah karena masih ada pembelajaran berikutnya. Kalau menyetor tugas, dituliskan sub temanya dan pembelajaran berapa. Masriadi (2018) mengutip penjelasan Poedjosoedarmo bahwa peserta tutur yang menentukan bentuk wacana atau tindak tutur komunikasi dan tempat tutur menunjukkan keadaan fisik bertutur, sedangkan suasana tutur menunjukkan keadaan psikologis tindak tutur. Tindak tutur guru sebagai bentuk kebijakan pembelajaran sejalan dengan penjelasan (Sukardi, 2018) bahwa keberhasilan kebijakan tergantung pada kepiawaian penutur menggunakan bahasa dalam membuat suatu kebijakan. Andianto et al., (2020)dalam penelitiannya menjelaskan bahwa peran dan fungsi positif jika kesantunan berbahasa ikut dipelihara, dilestarikan, dan dikembangkan. Faelani \& Setyowati (2018) menyatakan bahwa tindak tutur yang dilakukan guru bertujuan untuk menarik perhatian dan memengaruhi bahkan meyakinkan peserta didik agar melakukan yang diharapkan oleh seorang guru. Pemahaman kalimat dalam sebuah tindak tutur sudah ada sejak tata bahasa tradisional. Dalam tata bahasa tradisonal, kalimat dipahami berdasarkan pendekatan fungsi.

Berdasarkan hasil analisis terhadap tindak tutur guru SD Inpres Duyu, dapat disimpulkan bahwa pada dasarnya yang mendominasi tindak tutur adalah "kevariasian penyusunan kalimat" untuk menghasilkan daya informasi yang baik dan tidak membosankan, termasuk variasi penggunaan kata bersinonim, pengubahan urutan unsur kalimat, pemakaian bentuk aktif dan pasif, dan penyusunan kalimat panjang dan pendek untuk mendukung maksud tindak tutur

\section{Kesimpulan}

Bentuk tindak tutur asertif guru di SD Inpres Duyu terdiri atas tindak tutur menyatakan informasi, mengemukakan pendapat, menyimpul-kan, dan menegaskan. Tindak tutur dominan diawali oleh guru dan direspon serta ditindak-lanjuti dengan pengerjaan tugas-tugas oleh peserta didik.Fungsi tindak tutur guru di SD Inpres Duyu mengarah pada aspek-aspek informasi dalam fungsi secara luas yang disampaikan melalui media bahasa yang tidak dikodekan dalam sebuah konvensi umum dalam konteks kesantunan berbahasa tetapi secara alamiah. Fungsi tindak tutur guru di SD Inpres Duyu secara keseluruhan yaitu memiliki fungsi komunikatif yang memberikan informasi faktual, mengungkapkan emosi; meyakinkan dan mempengaruhi; serta menunjukkan sikap sosial dalam wujud komunikasi. Tindak tutur guru mengharapkan respon intelektual; sikap, dan moral yang berakhir dengan tindakan informasi intelektual dari penyelesaian tugas-tugas yang dikerjakan peserta didik.

\section{Referensi}

Andianto, M. R., Muti, A., Rijadi, A., \& Wuryaningrum, R. (2020). Pembelajaran Kesantunan Berbahasa.

Faelani, N., \& Setyowati, E. (2018). Tindak Tutur dalam Pembelajaran Bahasa Indonesia Siswa Kelas VII SMP Negeri 2 Pacitan Tahun Pelajaran 2016/2017. Jurnal Prakerta, 01(1), 54-62.

Masriadi, S.Kom, M. K. (2018). Vol. XII Jilid I No.79 Januari 2018 Menara Ilmu. XII(79), 80-93.

$\mathrm{Mu}$, A. (2019). No Title. Journal of Chemical Information and Modeling, 53(9), 1689-1699. Https://Doi.Org/10.1017/Cbo97811 07415324.004

Nurinna Arifiany, Maharani P. Ratna, S. I. T. (2016). Pemaknaan Tindak Tutur Direktif dalam Komik "Yowamushi Pedal Chapter 87-93." Journal of 
Chemical Information and Modeling, 53(9), 1689-1699. Https://doi.org/10.1017/cbo9781107 415324.004

Prayitno, J. H. (2009). Perilaku Tindak Tutur Berbahasa Pemimpin dalam Wacana Rapat Dinas: Kajian Pragmatik dengan Pendekatan Jender. Kajian Linguistik Sastra, 21(2), 132-146.

Purba, A. (2011). Tindak Tutur dan Peristiwa Tutur. Pena: Jurnal Pendidikan Bahasa dan Sastra, 1(1), 77-91. Https://onlinejournal.unja.ac.id/pena/article/view/ 1426

Rahayu, N. P. N. (2011). Bentuk dan Jenis Tindak Tutur Direktif dalam Film Le Dîner de Cons Karya Françis Veber.

Sukardi. (2018). Kebijakan Jokowi Terhadap Pandemi Corona Virus Disease 19 ( Covid-19 ): dalam Persfektif Tindak Tutur. Jurnal Edukasi Sumba (Jes), 4(2), 81-88.

Tidar, U., Kapten, J., No, S., \& Tengah, J. (2020). Tindak Tutur Asertif dan Formula Materi Ajar. 3(2010), 1-12.

Wahyuni, N. K. S. Y., \& Ekawati, N. W. (2018). Bahasa Indonesia. E-Jurnal Manajemen Universitas Udayana, 7(5), 2823. Https://doi.org/10.24843/ejmunud.2 018.v07.i05.p20

Wahyuni, S. T., Ratnawati, I. (2018). Tindak Tutur Ilokusi. 1(2), 11-18.

Yayat Sudaryat, M. H. (2006). Makna dalam Wacana Prinsip-Prinsip Semantik dan Pragmatik. 1-195. Https://doi.org/10.1080/09674845.2 $\underline{010.11730282}$ 